\title{
Front Matter: Volume 9419
}

, "Front Matter: Volume 9419," Proc. SPIE 9419, Medical Imaging 2015: Ultrasonic Imaging and Tomography, 941901 (4 May 2015); doi: $10.1117 / 12.2193824$

SPIE. Event: SPIE Medical Imaging, 2015, Orlando, Florida, United States 


\title{
PROGRESS IN BIOMEDICAL OPTICS AND IMAGING
}

\section{Medical Imaging 2015}

\section{Ultrasonic Imaging and Tomography}

\author{
Johan G. Bosch \\ Neb Duric \\ Editors
}

\section{2-23 February 2015}

Orlando, Florida, United States

Sponsored by

SPIE

\section{Cosponsored by}

Alpinion Medical Systems (United States)

Modus Medical Devices Inc. (Canada)

Bruker (United States)

ALIO Industries (United States)

Cooperating Organizations

AAPM-American Association of Physicists in Medicine (United States) - APS-American Physiological Society (United States) - CARS - Computer Assisted Radiology and Surgery (Germany) • Medical Image Perception Society (United States) • Radiological Society of North America (United States) - Society for Imaging Informatics in Medicine (United States) World Molecular Imaging Society• The DICOM Standards Committee

\section{Volume 9419}


The papers included in this volume were part of the technical conference cited on the cover and title page. Papers were selected and subject to review by the editors and conference program committee. Some conference presentations may not be available for publication. The papers published in these proceedings reflect the work and thoughts of the authors and are published herein as submitted. The publisher is not responsible for the validity of the information or for any outcomes resulting from reliance thereon.

Please use the following format to cite material from this book:

Author(s), "Title of Paper," in Medical Imaging 2015: Ultrasonic Imaging and Tomography, edited by Johan G. Bosch, Neb Duric, Proceedings of SPIE Vol. 9419 (SPIE, Bellingham, WA, 2015) Article CID Number.

ISSN: 1605-7422

ISBN: 9781628415094

Published by

SPIE

P.O. Box 10, Bellingham, Washington 98227-0010 USA

Telephone +1 3606763290 (Pacific Time) · Fax +1 3606471445

SPIE.org

Copyright (@ 2015, Society of Photo-Optical Instrumentation Engineers.

Copying of material in this book for internal or personal use, or for the internal or personal use of specific clients, beyond the fair use provisions granted by the U.S. Copyright Law is authorized by SPIE subject to payment of copying fees. The Transactional Reporting Service base fee for this volume is $\$ 18.00$ per article (or portion thereof), which should be paid directly to the Copyright Clearance Center (CCC), 222 Rosewood Drive, Danvers, MA 01923. Payment may also be made electronically through CCC Online at copyright.com. Other copying for republication, resale, advertising or promotion, or any form of systematic or multiple reproduction of any material in this book is prohibited except with permission in writing from the publisher. The CCC fee code is $1605-7422 / 15 / \$ 18.00$.

Printed in the United States of America.

Publication of record for individual papers is online in the SPIE Digital Library.

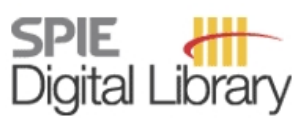

SPIEDigitalLibrary.org

Paper Numbering: Proceedings of SPIE follow an e-First publication model, with papers published first online and then in print. Papers are published as they are submitted and meet publication criteria. A unique citation identifier (CID) number is assigned to each article at the time of the first publication. Utilization of CIDs allows articles to be fully citable as soon as they are published online, and connects the same identifier to all online, print, and electronic versions of the publication. SPIE uses a six-digit CID article numbering system in which:

- The first four digits correspond to the SPIE volume number.

- The last two digits indicate publication order within the volume using a Base 36 numbering

system employing both numerals and letters. These two-number sets start with 00, 01, 02, 03, 04, $05,06,07,08,09,0 A, 0 B \ldots$. 0Z, followed by 10-1Z, 20-2Z, etc.

The CID Number appears on each page of the manuscript. The complete citation is used on the first page, and an abbreviated version on subsequent pages. 


\title{
Contents
}

\author{
vii Authors \\ ix Conference Committee \\ xi 2015 Medical Imaging Award Recipients
}

\section{SESSION 1 MOTION AND DEFORMATION IMAGING, NOVEL IMAGING APPROACHES}

941902 Transverse oscillation vector flow imaging for transthoracic echocardiography [9419-1]

941904 Automated hierarchical time gain compensation for in vivo ultrasound imaging [9419-3]

941905 Characterization of neonatal patients with intraventricular hemorrhage using 3D ultrasound cerebral ventricle volumes [9419-4]

941906 3D in vivo imaging of rat hearts by high frequency ultrasound and its application in myofiber orientation wrapping [9419-5]

\section{SESSION 2 KEYNOTE AND PHOTOACOUSTICS AND ACOUSTIC MICROSCOPY}

941909 Opto-acoustic image fusion technology for diagnostic breast imaging in a feasibility study [9419-8]

9419 OA Design and manufacturing of scanning probe acoustic microscope test phantom [9419-9]

9419 OB The study of photoacoustic imaging without nanoparticles as a contrast agent for antibody drug monitoring [9419-10]

\section{SESSION 3 ULTRASOUND COMPUTER TOMOGRAPHY I}

9419 OC Breast ultrasound computed tomography using waveform inversion with source encoding [9419-11]

9419 OD High-resolution quantitative whole-breast ultrasound: in vivo application using frequencydomain waveform tomography [9419-12]

9419 OE GPU-based 3D SAFT reconstruction including attenuation correction [9419-13]

9419 OF Bent ray ultrasound tomography reconstruction using virtual receivers for reducing time cost [9419-14]

$94190 \mathrm{~W}$ Whole breast tissue characterization with ultrasound tomography [9419-15] 
$9419 \mathrm{OH} \quad$ Implementation of swept synthetic aperture imaging [9419-16]

9419 ol In vivo real-time volumetric synthetic aperture ultrasound imaging [9419-17]

9419 OK Synthetic aperture imaging using a semi-analytic model for the transmit beams [9419-19]

9419 OM Wireless communication of real-time ultrasound data and control [9419-21]

\section{SESSION 5 ULTRASOUND COMPUTER TOMOGRAPHY II}

9419 OP Transducer elements position calibration in a ring array USCT system [9419-24]

9419 OQ Registration of 3D ultrasound computer tomography and MRI for evaluation of tissue correspondences [9419-25]

$9419 \mathrm{OR}$ Comparison of breast density measurements made using ultrasound tomography and mammography [9419-26]

\section{SESSION 6 ULTRASOUND IMAGE GUIDANCE: JOINT SESSION WITH CONFERENCES 9415 AND 9419}

9419 OS Respiration induced fiducial motion tracking in ultrasound using an extended SFA approach [9419-27]

9419 OT A-scan ultrasound system for real-time puncture safety assessment during percutaneous nephrolithotomy [9419-28]

9419 OU Surveillance of hemodialysis vascular access with ultrasound vector flow imaging [9419-29]

\section{SESSION 7 ULTRASOUND IMAGE ANALYSIS}

9419 OV Quantification of cerebral ventricle volume change of preterm neonates using 3D ultrasound images [9419-30]

9419 OW Quantitative ultrasound texture analysis for clinical decision making support [9419-31]

9419 0X Classification of kidney and liver tissue using ultrasound backscatter data [9419-32]

9419 OY An integrated framework for spatio-temporal registration of intravascular ultrasound pullbacks (Cum Laude Poster Award) [9419-33]

$94190 Z$ Iterative motion compensation approach for ultrasonic thermal imaging [9419-34]

941911 Parametric imaging of tumor perfusion and neovascular morphology using ultrasound [9419-36] 
941912 Research on respiratory motion correction method based on liver contrast-enhanced ultrasound images of single mode [9419-37]

941913 Time-frequency analysis of neonatal cranial ultrasonic movies for selective detection of pulsatile tissues by avoiding probe-motion artifact [9419-38]

941914 Ultrasound semi-automated measurement of fetal nuchal translucency thickness based on principal direction estimation [9419-39]

941915 Breast cancer detection based on time reversal and the optical theorem [9419-40]

941916 Breast ultrasound tomography with two parallel transducer arrays: preliminary clinical results [9419-41]

941917 Ultrasound bent-ray tomography with a modified total-variation regularization scheme [9419-42]

9419 1A Mapping viscoelastic properties by multi-line (ML) acoustic radiation force [9419-45]

9419 1B A new combined prior based reconstruction method for compressed sensing in 3D ultrasound imaging [9419-46]

$94191 \mathrm{C}$ Ultrasound coherence imaging using hardware receive beamforming and broad transmit beams [9419-47] 
Proc. of SPIE Vol. $9419941901-6$

Downloaded From: https://www.spiedigitallibrary.org/conference-proceedings-of-spie on 26 Apr 2023 Terms of Use: https://www.spiedigitallibrary.org/terms-of-use 


\section{Authors}

Numbers in the index correspond to the last two digits of the six-digit citation identifier (CID) article numbering system used in Proceedings of SPIE. The first four digits reflect the volume number. Base 36 numbering is employed for the last two digits and indicates the order of articles within the volume. Numbers start with 00, 01, 02, 03, 04, 05, 06, 07, 08, 09, OA, OB...0Z, followed by 10-1Z, 20-2Z, etc.

Aalamifar, Fereshteh, OX

Anastasio, Mark A., OC

Anis, Fatima, OC

Azuma, Takashi, OF, OP

Bednarz, Bryan, OS

Beland, Michael, OW

Bey-Knight, Lisa, OG, OR

Boctor, Emad M., OH, OX, OZ

Bottenus, Nick, $\mathrm{OH}, 1 \mathrm{C}$

Bouzari, Hamed, Ol

Boyd, Norman, OR

Bradway, David Pierson, 02

Brandt, Andreas Hjelm, 04, Ol, OU

Cao, Kunlin, OS

Cerrolaza, Juan J., ox

Chen, Ting, 16, 17

Chen, Xiaohui, OA

Chen, Yimin, OV

Chen, Zhi, OY

Chiu, Bernard, OV

Clingman, Bryan, 09

Dapp, R., OQ

de Ribaupierre, Sandrine, 05, 0V

Ding, Mingyue, $0 \mathrm{~A}$

Dornbluth, N. Carol, 09

Downe, Richard, OY

Duric, Neb, OC, OD, OG, OR

Epstein, Katherine, 16

Fang, Xiaoyve, OA

Fei, Baowei, 06

Fenster, Aaron, 05, OV

Fleming, loana, $\mathrm{OZ}$

Fonseca, Jaime C., OT

Foo, Thomas K. F., OS

Fukuzawa, Masayuki, 13

Gemmeke, H., OQ

Gierach, Gretchen L., OR

Glidden, David, OW

Gomyo, Mikako, 1 A

Grand, David, OW

Guo, Xiaoyu, $\mathrm{OZ}$

Hager, Gregory, $\mathrm{OZ}$

Han, Seung Hee, OB

Hansen, Jens Munk, OK

Hansen, Kristoffer Lindskov, 02, 04, OU

Hanson, Kenneth, 16

Hemmsen, Martin Christian, 04

Herzog, Don, 09

Hopp, T., OE, OQ
Hoyt, Kenneth, 11

Huang, Lianjie, 16, 17

Imoto, Haruka, OF, OP

Intrator, Miranda, 16, 17

Islam, Rafiqul, 1B

Izuwaki, Yusuke, 13

Jago, James, $\mathrm{OX}$

Jakovljevic, Marko, $\mathrm{OH}$

Jensen, Jørgen Arendt, 02, 04, 0l, OU

Jung, Haekyung, 14

Kang, Hyun Jae, $\mathrm{OZ}$

Kang, Jeeun, OB

Kim, Young II, OB

Kishimoto, Jessica, 05, 0V

Kist, Kenneth, 09

Kitsunezuka, Yoshiki, 13

Kondo, Kengo, 1A

Konrad, Joseph, OW

Kovarnik, Tomas, OY

Kretzek, E., OE, OQ

Krycia, Mark, OR

Lambert, Andrew J., 1B

Lavin, Philip, 09

Lee, David S. C., 05

Lee, Hyuntaek, 14

Lee, Mi-Young, 14

Lerakis, Stamatios, 06

Li, Cuiping, OC, OD, OG

Li, Tao, 12

Li, Yiyong, 12

Lin, Youzuo, 16, 17

Linguraru, Marius George, OX

Littrup, Peter, OG, OR

Lopez, John, OY

Marengo, Edwin A., 15

Martins, Bo, 04

Matsumoto, Yoichiro, OF, OP

Matthews, Thomas, OC

Merck, Derek, OW

Miller, Tom, 09

Moshavegh, Ramin, 04

Nakamori, Nobuyuki, 13

Nakamura, Hirofumi, OF

Nielsen, Michael Bachmann, 02, 04, OU

Nikolov, Svetoslav Ivanov, OI, OK

Olesen, Jacob Bjerring, OU

Oraevsky, Alexander, 09

Otto, Pamela, 09

Patwardhan, Kedar A., OS 
Pereira, W. C. A., OT

Pickering, Mark R., 1B

Qin, Xulei, 06

Qiu, Wu, OV

Qu, Xiaolei, OF

Rasmussen, Morten Fischer, 0 l

Rivaz, Hassan, OX

Rix, Marianne, OU

Rodrigues, Nuno F., OT

Rodrigues, Pedro L., OT

Roy, Olivier, OD, OG

Ruiter, N. V., OE, OQ

Safdar, Nabile, OX

Sak, Mark, OR

Sakuma, Ichiro, OF

Sandhu, Gursharan Yash Singh, OD

Sandoval, Daniel, 16

Schmidt, Steven, OD, OG

Seamans, John, OG

Shen, Ming, 06

Sherman, Mark E., OR

Shiina, Tsuyoshi, 1A

Shin, Junseob, 16, 17

Smith, L. Scott, OS

Song, Jitao, OA

Song, Tai-Kyong, $\mathrm{OB}$

Sonka, Milan, OY

Stavros, A. Thomas, 09

Stuart, Matthias Bo, 0 l

Tabata, Yuki, 13

Tahtali, Murat, 1B

Takagi, Shu, OF, OP

Tamano, Satoshi, OF, OP

Tobias, Richard J., OM

Trahey, Gregg E., OH, $1 \mathrm{C}$

Tu, Jing, 15

Tuomi, Adam, OW

Uddin, Muhammad Shahin, 1B

Ulissey, Michael, 09

Umemura, Shin-Ichiro, OF, OP

Üstüner, Kutay F., 1C

Vilaça, João L., OT

von Krüger, M. A., ОT

Wagner, Mary B., 06

Wahle, Andreas, OY

Wallen, Andrea, OG

Wang, Kun, OC

Wang, Silun, 06

Williamson, Michael, 16

Wilson, Brian, $\mathrm{OB}$

Won, Hye-Sung, 14

Wu, Jie Ying, OW

Yamakawa, Makoto, $1 \mathrm{~A}$

Yoon, Heechul, 14

Zalev, Jason, 09

Zapf, M., OQ

Zhang, Ji, 12

Zhang, Ling, OY

Zhang, Xiaodong, 06

Zheng, Shiqiang, 12

viii

Proc. of SPIE Vol. $9419941901-8$ 


\title{
Conference Committee
}

\author{
Symposium Chairs
}

David Manning, Lancaster University (United Kingdom)

Steven C. Horii, The University of Pennsylvania Health System

(United States)

Conference Chairs

Johan G. Bosch, Erasmus University Rotterdam (Netherlands)

Neb Duric, Delphinus Medical Technologies (United States) and Barabara Ann Karmanos Cancer Institute (United States)

\section{Conference Program Committee}

Jeffrey C. Bamber, The Royal Marsden NHS Foundation Trust

(United Kingdom)

Jan D'Hooge, Katholieke Universiteit Leuven (Belgium)

Marvin M. Doyley, University of Rochester (United States)

Stanislav Y. Emelianov, The University of Texas at Austin

(United States)

Mostafa Fatemi, Mayo Clinic College of Medicine (United States)

Aaron Fenster, Robarts Research Institute (Canada)

Jérémie Fromageau, The Institute of Cancer Research

(United Kingdom)

James F. Greenleaf, Mayo Clinic (United States)

Emma J. Harris, The Institute of Cancer Research (United Kingdom)

Martin Christian Hemmsen, Technical University of Denmark

(Denmark)

Brecht Heyde, Katholieke Universiteit Leuven (Belgium)

Michael Jaeger, Universität Bern (Switzerland)

Jørgen Arendt Jensen, Technical University of Denmark (Denmark)

Hyung Ham Kim, University of Southern California (United States)

Roman G. Maev, University of Windsor (Canada)

Stephen A. McAleavey, University of Rochester (United States)

Serge Mensah, Aix-Marseille University (France)

Svetoslav I. Nikolov, BK Medical (Denmark)

Olivier Roy, Karmanos Cancer Institute (United States)

Nicole V. Ruiter, Karlsruher Institut für Technologie (Germany)

Kai E. Thomenius, General Electric Company (United States)

William F. Walker, University of Virginia (United States) 
Session Chairs

1 Motion and Deformation Imaging, Novel Imaging Approaches

Brecht Heyde, Katholieke Universiteit Leuven (Belgium)

2 Keynote and Photoacoustics and Acoustic Microscopy

Neb Duric, Delphinus Medical Technologies (United States)

3 Ultrasound Computer Tomography I

Nicole V. Ruiter, Karlsruher Institut für Technologie (Germany)

4 Transducers, Beamforming, Systems

Jørgen Arendt Jensen, Technical University of Denmark (Denmark)

5 Ultrasound Computer Tomography II

Neb Duric, Delphinus Medical Technologies (United States)

$6 \quad$ Ultrasound Image Guidance: Joint Session with Conferences 9415 and 9419

Cristian A. Linte, Rochester Institute of Technology (United States)

Johan G. Bosch, Erasmus University Rotterdam (Netherlands)

$7 \quad$ Ultrasound Image Analysis

Johan G. Bosch, Erasmus University Rotterdam (Netherlands) 


\section{Medical Imaging Award Recipients}

\section{Robert F. Wagner Best Student Paper Award}

Robert F. Wagner was an active scientist in the SPIE Medical Imaging meeting, starting with the first meeting in 1972 and continuing throughout his career. He ensured that the $\mathrm{BRH}$, and subsequently the $\mathrm{CDRH}$, was a sponsor for the early and subsequent Medical Imaging meetings, helping to launch and ensure the historical success of the meeting. The Robert F. Wagner All-Conference Best Student Paper Award (established 2014 ) is acknowledgment of his many important contributions to the Medical Imaging meeting and his many important advances to the field of medical imaging.

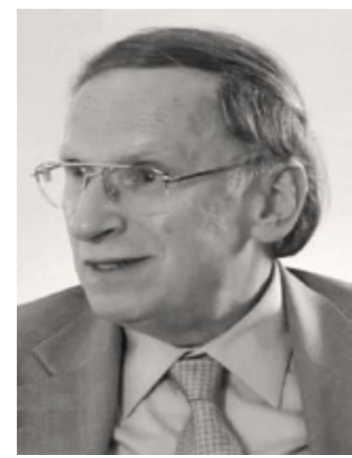

This award is cosponsored by:

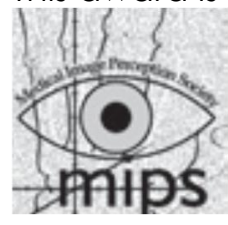

The Medical Image Perception Society

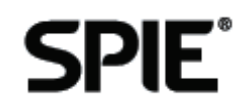

\section{Recipients:}

First Place: Automatic discrimination of color retinal images using the bag of words approach (9414-54)

I. Sadek, D. Sidibé, F. Meriaudeau, Univ. of Burgundy (France)

Second Place: Automated pulmonary lobar ventilation measurements using volumematched thoracic CT and MRI (9417-42)

F. Guo, S. Svenningsen, E. Bluemke, M. Rajchl, J. Yuan, A. Fenster, G. Parraga, The Univ. of Western Ontario (Canada)

\section{Conference Awards}

\section{Recipients:}

Cum Laude Poster Award (First Place): An integrated framework for spatio-temporal registration of intravascular ultrasound pullbacks [9419-33]

L. Zhang, A. Wahle, Z. Chen, lowa Institute for Biomedical Imaging (United States) and The Univ. of lowa (United States); R. Downe, lowa Institute for Biomedical Imaging (United States); J. Lopez, Loyola Univ. (United States); T. Kovarnik, Charles Univ. in Prague (Czech Republic); M. Sonka, University of lowa (United States) 
Proc. of SPIE Vol. $9419941901-12$

Downloaded From: https://www.spiedigitallibrary.org/conference-proceedings-of-spie on 26 Apr 2023 Terms of Use: https://www.spiedigitallibrary.org/terms-of-use 